\title{
The Spatial Production of Public Parks and Counter-public Non-parks in Tapei *
}

\author{
Min Jay Kang \\ National Taiwan University, Taiwan \\ kminjay@ntu.edu.tw
}

\begin{abstract}
This research differentiates counter-public non-parks from public parks to look into the spatial politics and social processes behind the productions of urban parks and open greens in the city of Taipei. The colonial modernity ushered in the concept of public parks in Taipei, though under the authoritarian ruling the meaning of publicness was problematic and the discourse surrounding the public sphere underdeveloped. The process of democratisation in the post-1980s eras activated the grassroots engagement in politics and further nurtured the bottom-up mechanism of counter-publics in a conservation movement and in claiming their rights to the city. The paradigm of counterpublic non-park defied the general definition and used patterns of public parks, and advocated a more socially inclusive and culturally diverse program for the alternative public green. Non-park implies either the unregulated land use patterns that are endured within the zoned parks or the publicly shared open greens that are not officially designated as public parks. It also motivated the transformation of settlementinto-park to settlement-park and responded to the call for dynamic urban conservation. This research looks into the coexistence of parks and non-parks in Taipei's Da-an District, and concludes that the variegated park paradigms are conducive to the development of a more democratic and progressive city that sustains a broader comprehension of public history.
\end{abstract}

Keywords: public park, counter-public non-park, settlement-into-park, settlement-park, subaltern counter-publics, landscape urbanism, Da-An Park, Taipei

* The designations employed do not imply the expression of any opinion whatsoever on the part of the Secretariat of the United Nations concerning the legal status of any country, territory or area, or of its authorities.

To cite this article:

Kang, M. J. (2019). The Spatial Production of Public Parks and Counter-public Non-parks in Tapei. The Journal of Public Space, 4(2), I0I-I22, DOI I0.3289I/jps.v4i2.II 57

This article has been double blind peer reviewed and accepted for publication in The Journal of Public Space.

This work is licensed under a Creative Commons Attribution - Non Commercial 4.0 International License https://creativecommons.org/licenses/by-nc/4.0/ 


\section{Introduction: the emergence of counter-public non-parks within the public park system in Taipei}

The concept of park in modern urban planning is derived from the logic of land-use zoning to provide public facilities for urban recreation and nature reserve. Yet the production of a park, regardless of its affiliation with nature, is a political contention embedded in the urbanisation of a "socio-ecological process" (Heynen et al, 2006). The first park in Taipei appeared in 1897 during the Japanese colonial period as a demonstration of modernist planning as well as a proposition of the ruling power for the urban green system. In 1932, the green infrastructure network for the capital city of Taipei had been mapped out to illustrate an environmental vision as well as a symbol of "colonial modernity" (Barlow, 1997; Wu, 2010), and though only partially implemented, it had become the guiding scheme for the post World War II follow-up plan of the Nationalist government. Park is also a manifestation of publicness and openness, and its land is oftentimes publicly-owned. But in a time of non-democratic governance, the meaning of publicness might be questioned or disputed.

According to the executive procedure of Taiwanese urban planning, the tool of eminent domain or expropriation would be employed to acquire land for the park, unless it is publicly owned. The original landscape would then be razed to ground zero to accommodate new plan and design. However rational it may sound, this process of park implementation instigated many serious conflicts and controversies, especially when the political conundrum and housing deficiency of the post-War development were brought to the fore.

During the first-phase of the Nationalist governance, the KuoMinTang (KMT) government did not relinquish the plan of reclaiming Mainland China, and showed little motivation towards 'localising' the practices of urban and housing policies. Under the circumstances of inadequate housing provision, a high volume of political immigrants who followed Chiang Kai-Shek's retreat to Taiwan began to occupy underdeveloped public land to self-build transitional housing collectively and agglomerate them into many types of temporary settlements. Among all the occupied urban land, a significant percentage was still zoned for park use succeeding the Japanese colonial plan, including the larger tracts of Park \#7, \#I2, \#I4, \#I5, etc. in Taipei alone.

In fact, the KMT government also 'illegally' built legal military-dependents' housing compound inside the parkland, for instance Park \#7 (later-day Da-An Park), to accommodate the families of the higher-ranking political immigrants. Yet there were more 'illegal' military-dependents' settlements of the lower-rank veterans' families growing organically around the legal housing compound, followed by self-built dwelling units of the rural-urban immigrants who sought for cheap housing resources in the city since the 1970s. What was planned to be public parkland gradually evolved into 'private' yet collective homeland for the underprivileged citizens after several decades. But when the deadline of expropriating private land for implementing zoned public facilities drew near, the government had to take a drastic measure to evict all inhabitants and demolish all existing buildings. The ultimate fate of 'settlement-into-park' appeared to have

\footnotetext{
' 'Settlement-into-park' exemplifies a particular type of urban park that replaces its predecessor of living settlements through the tools of urban zoning and eminent domain, for instance, Kolkata's Maidan Park and New York City's Central Park.
} 
responded to the public quest for urban green and zoning enactment, it also mercilessly disintegrated strong identifications of places and tightknit neighbourhood networks.

Many of the government-built or squatter villages on the parklands had existed since the post-World War II era until their final terminations, yet the inhabitants' living experiences and collective memories established for more than half of a century were hardly recognised to be of historical value in the face of park implementation. The settlement inhabitants were coerced to confront different conditions of diaspora (a part of the military dependents even suffered double diasporas). Some were fortunate enough to be resettled into new public housing, but some became victims of compulsory displacement. The spatial production of parks in Taipei ironically triggered a new agenda of claiming right to the city and housing justice by settlement inhabitants and progressive advocates, and expanded into social movements of settlement conservation and rewriting "public history" (Hayden, 1996) for the disempowered social groups. The conservation movement was not a return to nostalgia; instead, it activated a revival of spatial meanings and a mobilization of placemaking. The subaltern society and the marginalised social groups, resisting forced displacement, kindled spatial imagination of the 'counter-publics' through the mechanism of bottom-up selforganization and participatory planning, and asserted a more socially and culturally inclusive park paradigm to differentiate itself from the general public park simply obeying the zoning definition and ordinances.

Consequently, the counter-public non-park is referred to as an open green or semi-park space beyond park administration or zoning ordinances, including a type of settlementpark $^{2}$ that may exceed the regulated I5\% building coverage ratio, and different types of quasi-park that either allows residential and other 'privatising' activities inside the park, or takes advantage of the transitional period of development to create green open space, or challenges the general but constrained conception of publicness within park use, or exhibits publicly-shared green zone yet inappropriately zoned. The non-park, however, can be located in official parkland, only that its counter-public trait or its process of spatial production brings a twist to the common perception of a public park. The non-park ${ }^{3}$ generated via settlement conservation is not an anti-park, but to transform the urban planning rationale of settlement-into-park into a type of settlementpark that integrates settlement morphology and open green. From the preservation of settlement fabrics to the dynamic conservation of sustaining living patterns and community networks of the underprivileged settlement counter-publics, settlement parks in Taipei have developed distinctive detailed plans under a mixed effect of zoning ordinance and the cultural heritage preservation act.

Fraser (1992) proposes the critical concept of subaltern counter-publics to challenge the little questioned "bourgeoisie public sphere" and the mass publics that exclude the underprivileged others, such as women, labourers, and the subordinated class, from the discourses and mediations of the public sphere. Fraser regards that the idealised public sphere according to Jurgen Habermas is single and unitary, contradictory to the

\footnotetext{
2 'Settlement-park' represents a park form incorporating the original settlement fabrics into park design, such as Virginia's Jamestown Festival Park or Sydney's Foundation Park (the Rocks).

${ }^{3}$ Non-park, an affix derived out of park, is deliberately coined to exemplify the cases of either the unregulated land use patterns that are endured within the zoned parks or the publicly shared open greens that are not officially designated as public parks.
} 
publicness "composed of the conflictual and antagonist publics" (Kampourakis, 20I6). Fraser reworks the discourse of publicness to underline subaltern counter-publics against the dominant publics, and urges the formation and emergence of a contesting identity of the subaltern society, deliberately overlooked and suppressed by the traditional public sphere, to participate in the production of public meanings. Warner (2002: 63) also remarks, "mass publics and counter-publics" are "both damaged forms of publicness, just as gender and sexuality are, in this culture, damaged forms of privacy." In line with the counter-publics discourse, the use of counter-public in this research intends to reveal the often-excluded or -displaced statuses or spaces by the designated public realm of urban planning, and counter argue the substantial role of nonparks in the open city.

This research is concerned about the contrasting politics of the productions of parks and non-parks, and how such politics is embedded in the modernising and concomitantly democratising and liberalising processes. How do these processes confront and foster publicness while at the same time begets the effect of exclusion and expulsion, if maximum publicness infers upmost social inclusion? How do the counter-publics reconstruct public history and spatial narratives through their participation in the development of non-parks?

\section{The quest for urban park and the landscape urbanism turn in urban planning and design}

Christopher Alexander was right: a city is not a tree. It is a landscape.

-Tom Turner, 1996

Inheriting the park tradition established by the most influential landscape theorist and practitioner Frederic Law Olmsted, many cities reserve large parks to sustain the regional characteristics and the integrity of ecology. Czerniak (2007) cites Olmsted and the pioneering landscape architects as the devotees of large parks and traces back how the reserved large open spaces have upheld the ecological sink of the green infrastructure and affected urban public life. But she also reminds us that in the democratic city the processes of shaping large parks are far from those of the authoritarian time, and the entanglement of environmental justice, land justice, social justice, and procedural justice may even question the legitimacy of acquiring large parcel of land for park use only.

In recent years, the concept and design principles of landscape urbanism have brought together the different disciplines of landscape architecture, architecture, urban planning and design, ecological planning, and urban studies to reinvestigate and intervene in the urban processes through large-scale green implementations. Its dynamic interlocking of the spatial and temporal dimensions stimulates the design profession to be more sensitive to the ever-changing nature of the city (Connolly, I995; Mostafavi et al, 2003). The Design with Nature (1969) methodology of lan McHarg cast a lasting impact on landscape urbanism and further integrated the research on nature into the process of 
design. His disciples, most noteworthy James Corner ${ }^{4}$ and Charles Waldheim ${ }^{5}$, carry his legacy to the theoretic frameworks of landscape architecture and reinforce the mode of incorporating the ecological system of nature and its reserve to the green infrastructure of urban design. Yet in the scope of landscape urbanism, the process of nature is much accentuated over the political process of urban governance.

Comparatively, the paradigm of new urbanism ${ }^{6}$ is another post-modern urban design approach that is critical to the frequent de-contextualisation of modernist architecture and zoning-based urban planning, while emphasising incongruent urban values from those of landscape urbanism that both have, to certain degree, become mutual critiques of each other. Advocates of new urbanism criticise landscape urbanism for its lack of understanding of density and bona-fide urbanism and for its ignorance of what urban streets mean to the pedestrians and living communities while proposing and designing expensive 'green' projects that in reality proliferate urban sprawl. But landscape urbanists disdain the nostalgic genes of neo-classicism in the skeleton of new urbanism and how it has evolved into a new authority of urban design without the sensitivity of ecological diversity and sustainability (Steuteville, 20l I).

From the urban experiences of the Global North, landscape urbanism indeed cares more about the strategic layout of large parks than the street front living or the articulation of green system with the residential communities and street life. In the builtup areas of compact cities, the challenges of expropriating the urban land for the implementation of green infrastructure are enormous. The highly publicised case of the High Line is a rare realisation of landscape urbanism within the fine-grained urban texture without manoeuvring large public spending to acquire the land. On one hand, the project helps regenerate a linear corridor of the run-down industry in west Manhattan and attract millions of New Yorkers and global tourists to visit the creative reuse design of the nullified rail system each year; yet on the other, the abutting neighbourhoods of the High Line are caught in the new struggles of "green gentrification" (Gould and Lewis, 2016) and vertical expansion of developments (Speckhardt, 20I4). The aspect of political economy associated with any urban landscape is an issue that landscape urbanism cannot ignore, but it is oftentimes unheeded or simplified in the process of design where it is presumed that 'open-ended' landscape evolution may be quickly terminated by the logic of capital. This happens to be a problem for new urbanism as well, as Harvey (1997) rightly points out, in that it forges communitarian rhetoric of nostalgia to activate an urban agenda of de-stratifying social classes and homogenising differences and to thereby creates a 'new' urban condition embracing neighbourly life and formal aesthetics of a village.

\footnotetext{
${ }^{4}$ Corner (2006), modifying the tradition of Design with Nature, identifies a few principles that are critical to the realization of landscape urbanism, including the horizontal alignment of landscaping in restructuring the city, adaptive working methods and techniques that respond to the constraints and potentials of local environment, enriching imagination to foster new possibilities and relationships, and a respect for natural processes to facilitate a fluid design over time that creates open-ended, flexible, and negotiable urban dialogues.

${ }^{5}$ Waldheim (2002) exemplifies the open design of landscape urbanism and regards the spatial program of the park as a changeable process that deploys layered events and activities in a non-hierarchical layout. ${ }^{6} \mathrm{New}$ Urbanism focuses on designing urban villages with vital street life and a sense of neighbourhood through pedestrian-oriented development (POD) and transit-oriented development (TOD) (Kelbaugh, 2002).
} 
In I99I, the city of Seattle attempted an approach of landscape urbanism and proposed a large park known as Seattle Commons in the functional light industrial area south of Lake Union to be connected with downtown, and one of the founders of Microsoft Paul Allen endorsed the proposal with substantial finance. The Cascade community and I 30 light industry companies that were about to be replaced decided to resist the top-down planning of the 25-hectare Seattle Commons and counter campaign against the joint speculation of the corporate power and the state. They argued that voters for the park initiative should consider the cultural and industrial sustainability of the Cascade neighbourhood and the city should wisely allocate the tax revenue in the improvement of neighbourhood parks and schools instead of building a new de-contextualised large park where few citizens would commute to use or real estate would profit from. Their bottom-up voices made a persuasive contention, and in the referendum dated $19^{\text {th }}$ of September 1995, the voters vetoed the park proposal with a margin of $53 \%$ to $47 \%$ (Higgins, 1995). It was an indicator of how landscape urbanism, with strong environmental vision and ecological concern, might still be disconnected with the everyday urbanism of street vitality and the immediacy of social agenda.

Till today, Seattle Commons remains a castle in the air while the real estate value of the proposed area continues to boom. The publicness of public parks is not unquestionable and it needs to be addressed in public discourses beyond the green rhetoric. In a democratic process of park development, different options of green urbanism and green infrastructure can thereby be planned and evaluated. Is a large park bordered by lines of park-view development more favourable than a series of smaller neighbourhood parks embedded in living neighbourhoods? Can counter-public non-parks be deployed in a zoned and regulated public park system? Based on which perspective, ecological, social, or cultural? And whose benefit of public green is guarded, the green real-estate developers, the bourgeoisie publics, or the subaltern counter-publics?

Drawing on David Harvey's concept of spatial fix (200I), Loughran (20I8) regards the development of urban park as a "cultural fix" and that "parks and other green spaces structure property values, but they also provide essential sites of political exchange, social control, recreation, and cultural production." Cranz (1982) exemplifies that park has always been associated with the social reform movements of different eras and represents how the social elites manipulate their powers to intervene and dictate the public agenda via reform programs on the footing of social welfare and public wellbeing. From this perspective, park can be seen as a planner's tool to spatially mediate social problems, Tsai (I99I), tracking Cranz's socio-political analysis of urban park and the formation of local urban park landscape, interprets park as a projection and aspiration for the rational urban form and an ideological outreach of the ruling regime. The production of Taiwanese urban parks is therefore embedded in the "policy mobility" (McCann and Ward, 20I5) of local politics and national policy ${ }^{7}$ along the process of its own democratisation.

\footnotetext{
${ }^{7}$ McCann and Ward (2015) argue that urban policy mobility should be conceptualised through "relational dyads, rather than oppositional dualisms."
} 


\section{Research methods}

This research employs different modes of field investigation, including participatory observations, unstructured interviews, and field notes, as well as secondary source and critical analysis, overlay of historical maps, and GIS mapping to conduct a comprehensive survey of parks and non-parks in Taipei's Da-An District. Some of the interviews related to the collective memory of the settlements in the park were conducted in the annual Da-an Park Ecological Fair, where some of the past inhabitants or neighbours strolled into our exhibition booth to read the old maps and photos and watch film clips. Many photos were purchased from the archives of the Central News Agency, and the historical maps were searched from the document of the Centre for GIS, RCHSS (Research Centre for Humanities and Social Sciences) of Academia Sinica. The method of auto ethnography, using self-reflecting writing to connect personal experiences with broader cultural context and explore the social meaning of specific events, is also employed in the non-park analysis. A few case studies outside the main researched area but related to the core arguments are also comparatively analysed.

\section{The urban politics behind the productions of Taipei's parks and non-parks} The colonial green plan for Taipei was laid out long before the theory of landscape urbanism emerged to become the guiding principles of implementing urban infrastructure, but their visions and approaches are in accordance. The effect of the colonial plan, however, did not come to fruit till the 1980s when the deadlines for implementing designated public facilities were about to expire. It was also a time when the Martial Law was lifted and the grassroots began to flex their muscles, and the change of the political climate prompted the critical actions against the top-down imposition. The following sections illustrate the different routes of facilitating public parks and their counterpart non-parks in Taipei.

\section{I Urban parks and open space system under Taipei's urban planning scheme}

The quest for urban parks in the immigrant city of Taipei was in question and deferred when the demand for housing in the post-War era surpassed any other urban concern of collective consumption. The population of Taipei surged up from 270,000 in 1946 right after World War II to 560,000 in 195I, the post-War political immigrants nearly collapsed the Japanese colonial planning capacity of maximum 600,000 people in less than 5 years. In the statistics of 1963, there were 292,894 people living in illegal self-built housing, about $28.13 \%$ of the overall population. Many of them chose to squat on the undeveloped land zoned for public park use, hardly aware of the consequence of stigmatisation and eviction after a few decades (Kang, 20I5). On the other hand, the unchallengeable transition of land ownership from the colonial state to the KMT regime released the largest share of urban land to the Ministry of National Defence, which activated the building of many military-dependents housing clusters after their coerced acceptance of the islands of Taiwan as the long-term refuge for the political immigrants. But that being recognised, many of the clusters were established on the parkland and two of them were located in one of the largest planned urban parks of Taipei, Da-An Park. 
The composite uses of the demarcated land for Da-An Park before its eventual implementation were dynamic and chaotic, including, other than the formal and informal housing clusters for military dependents, temples, churches, International House of Taipei, squatter houses for rural-urban immigrants, cemetery, military police barracks, military radio station, markets, eateries, auto repair shops, recycling centre, and so on that accommodated a huge urban settlement of more than I2,000 people (Huang, 1997). The political decisions of turning the occupied land into a park were in certain way an official response to the original colonial urban plan, but not without serious debates. The major challenge came from the proposal of a gymnasium dome, which replicated other precedent or later transformations of parkland into public facilities and incurred criticism from environmentalist groups in the late 1980s when Martial Law was lifted and the democratising process was at its peak. In 1991, the then-mayor of Taipei Huang Da-zhou declared that the land would be reserved only for Da-An "Forest" Park and determined to relocate or demolish all of the existing features on the parkland except for, controversially, an iconic Buddhist statue of Gaun-Yin (Goddess of Mercy). The tall freestanding Guan-Yin statue used to be a part of an illegal temple in the park zone and worshipped by many Buddhist pilgrims and passers-by. The neighbouring HsinSheng South Road was nicknamed 'Way to Heaven' and famous for accommodating a variety of religious institutes along the way, including four different Christian churches, one Catholic church, and one Islamic mosque. When a group of protesters gathered in front of the statue to passionately defend its deemed irreplaceable position, the in-situ preservation of Guan-yin immediately turned into an identity politics of religion. The legitimacy of preserving a singular religious symbol in a public park was questioned in a democratising society that asserted coexistence of diverse cultures and religions. After many rounds of negotiations, the government came to an unusual solution to claim the statue as an object of public art thanks to, luckily, the creator of the statue being a renowned sculptor Yang Ying-Feng. In order to differentiate a religious icon from a 'public' art, the government also erected a signboard that declared Guan-Yin as an artwork dedicated to the public through private donation and all worshipping and religious activities would be thence prohibited. The declaration is still in effect today, but impromptu praying and worshipping pilgrimage are easily spotted on site while the official reminder is always overlooked. The perpetuated standing of the Guan-Yin statue in Da-An Park becomes a testament of publicness being a process of contending urban meanings and identities.

The common homeland for the military-dependents and the squatters of multiple generations was not recognised as a 'public' asset; rather, it was disparaged as an infringement on publicness. Many political immigrant families and underprivileged citizens were forced to confront the second-time diaspora and make their ways for the "green bulldozer" (Huang, 20I2). The illegal status of the squatters was a consequence of the inadequacy of post-War housing policy and provision, their self-help and self-built tactics of survival actually helped alleviate the crisis of the governance of KMT. Yet decades of identification with a place and a vibrant neighbourhood was labelled as a detriment to public green and fell victim to the advent of a large park. A popular movie of 1983 Papa Can You Hear Me Sing? (Da-Cuo-Che, 搭錯車) intentionally blended the pre-park village into the set of low-end living in the face of impending demolition and became a sour note of the park development in Taipei. The issue of public inclusion is 
most acute when contrasting the evicted community with the prime real estate surrounding Da-An Park today.

The controversy of green bulldozer and green real estate continued when the sites of \#I4 and \#I5 Park encountered similar situation of ousting the squatter villages of political immigrants for the open green in the mid-1990s. The two designated parks were adjacent and located in another prime location of urban development, only separated by a south-north boulevard. Unsurprisingly, the adjoining neighbourhoods and commercial strips that perceived fronting park as a major boost for real estate value embraced the reclamation of public land for planned parks. But the squatter community that had little resources requested in-situ rebuilding or building new housing for resettlement before demolishing the old settlements. The academics, students, and activists joined the disempowered inhabitants to initiate an influential movement that counteracted the manoeuvre of the 'governmental bulldozers' and the rationale of parks over homeland. What appeared to be neutral and unquestioned publicness of parks became highly politicised and its understated role as a medium for land speculation was seriously criticised and re-evaluated. The anti-governmental bulldozer movement was considered to be the major resistance forefront of civil disobedience since Snails without Shells Housing Movement of 1989.

Even though six unknown fires burned down the entire squatter villages on Park \#I4 and \#I 5 on the evening of eviction and paved the way for park implementation, the legacy of anti-governmental bulldozer motivated the other counter-public actions and bottom-up conservation projects in different parts of the capital city that challenged the taken-for-granted idea of public spheres. In 1998, different communities under the threat of the governmental bulldozer self-organised to hold the Exposition of Disempowered Communities at Taipei's Treasure Hill, another squatter settlement zoned to be razed for a park. Through lobbying and petitioning for the mayor candidates at that time to sign a 'voucher' of conservation and rebuilding, the political manoeuvring later facilitated the new and more progressive paradigm of counter-public non-parks.

Eventually, Da-An Park was completed and open to the public in 1994 with a bleak image of dirt, unhealthy trees, and incomplete facilities. Mayor Huang Da-Zhou was criticised for the hurried implementation and lost his seat, but it was a rare fulfilment of a colonial legacy back in 1932. Fig. I illustrated the comparison of the Planning of Park and Green Parkway of 1932 with the present-day green resources layout plan, and the 1932 plan (in slash lines) prescribed a green infrastructure on Taipei's undeveloped eastside but later modified into patches of green in diversified neighbourhoods. Even though the KMT government basically followed the colonial order for the post-War urban planning of Taipei, many open spaces of larger parks were replaced by building coverage ranging from San Yat-sen Memorial (Park \#6), Taipei Arena (Park \#5), Hakka Cultural Compound (Park \#II), to Floral Expo Buildings (Par \#3 and \#4) over the years, and the north-south green boulevard connecting the large parks was also changed into an elevated auto speedway. The colonial green plan exhibited an intention and ambition comparable to the theorised landscape urbanism, but Da-An was the few cases of retaining the open green of large parks with minor adjustment along the road edges. The horizontality of landscape urbanism conceived by colonial modernity still receded to the verticality of urban development after all. 


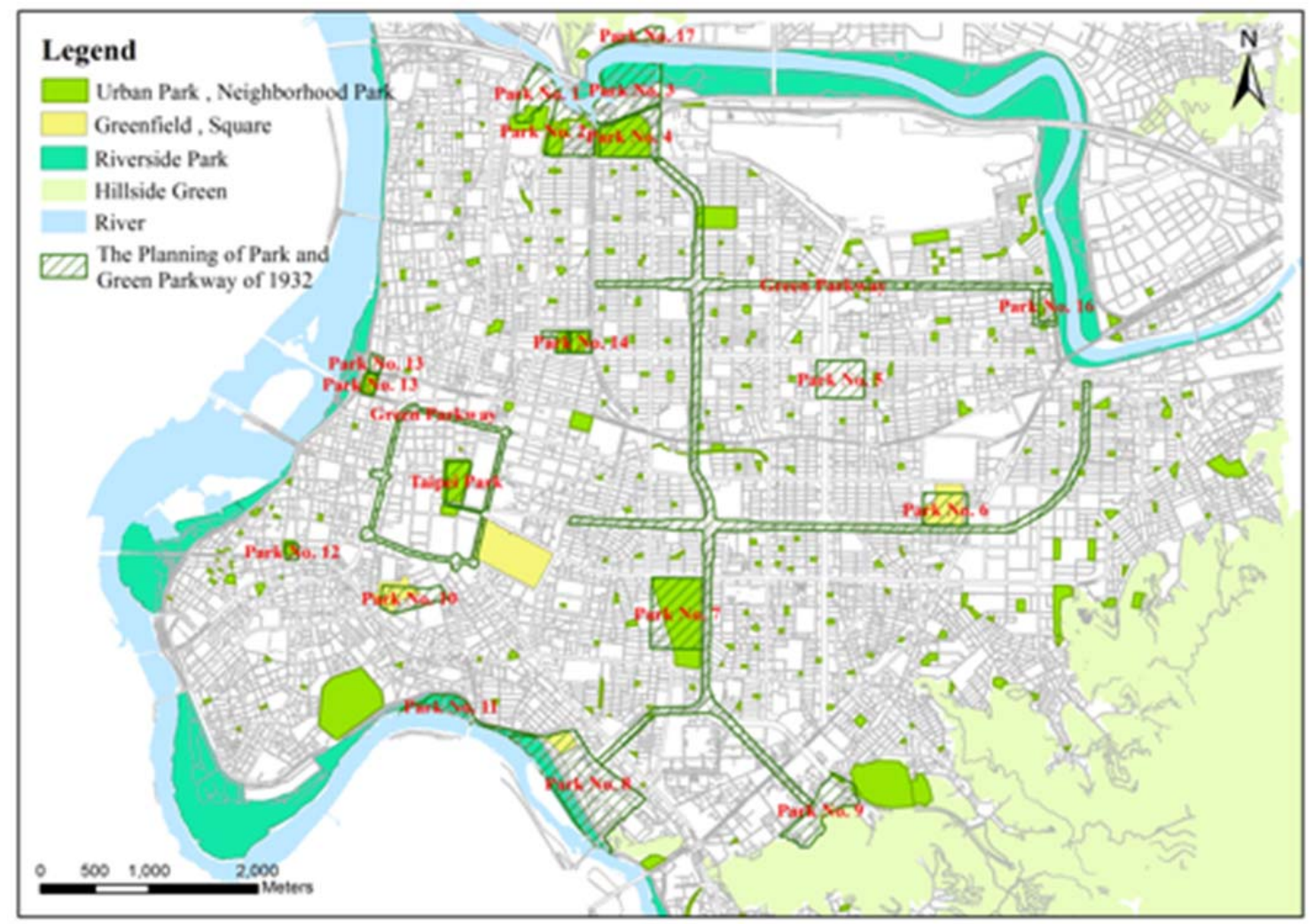

Fig. I. Comparison of the Planning of Park and Green Parkway of 1932 and the present-day green layout plan

The 1932 colonial green plan deployed the larger parks around the river bend or the foothill of mountains to take the best advantage of natural resources, while the parks inserted among the urban blocks anchored the green system of the not-yet developed eastside areas at a few strategic locations. Though the 1932 plan was never fully realised due to the interruption of war, the colonial government activated the critical implementation of the 1936 Taiwan Urban Planning Act to establish the mechanism and tools of zoning and urban administration. Accordingly, $3 \%$ of the consolidated land for district residential development would be reserved for small neighbourhood parks, and between 1937 and 1942, altogether 54 neighbourhood parks in five planned residential blocks for the Japanese were confirmed and by 1942, II of them were completed for 'public' use (Liu, 2005). This could be regarded as the inception of Taipei's small or neighbourhood parks, but it was also questionable how public it could be considering the segregation of the Japanese neighbourhoods from the city at large. In the urban planning map of $195 \mathrm{I}$ (Fig. 2), a few small parks (in red circles) could be identified in the neighbourhoods north of the still undeveloped Da-An Park. The same year, the $\$ 1.48$ billion US Aid began to reshape many urban infrastructure and modernist housing developments through transnational finance and technical assistance. Between I95I and 1965, many public buildings and neighbourhoods were directly or indirectly constructed via the loan and planning advices of the Western institute. Since 1965, the founded colonial system was also modified by the suggestions of U.N. Advisory Group and UHDC (Urban and Housing Development Committee), which 
enhanced the concept of planned neighbourhood units that lay emphasis on accessible green public parks.

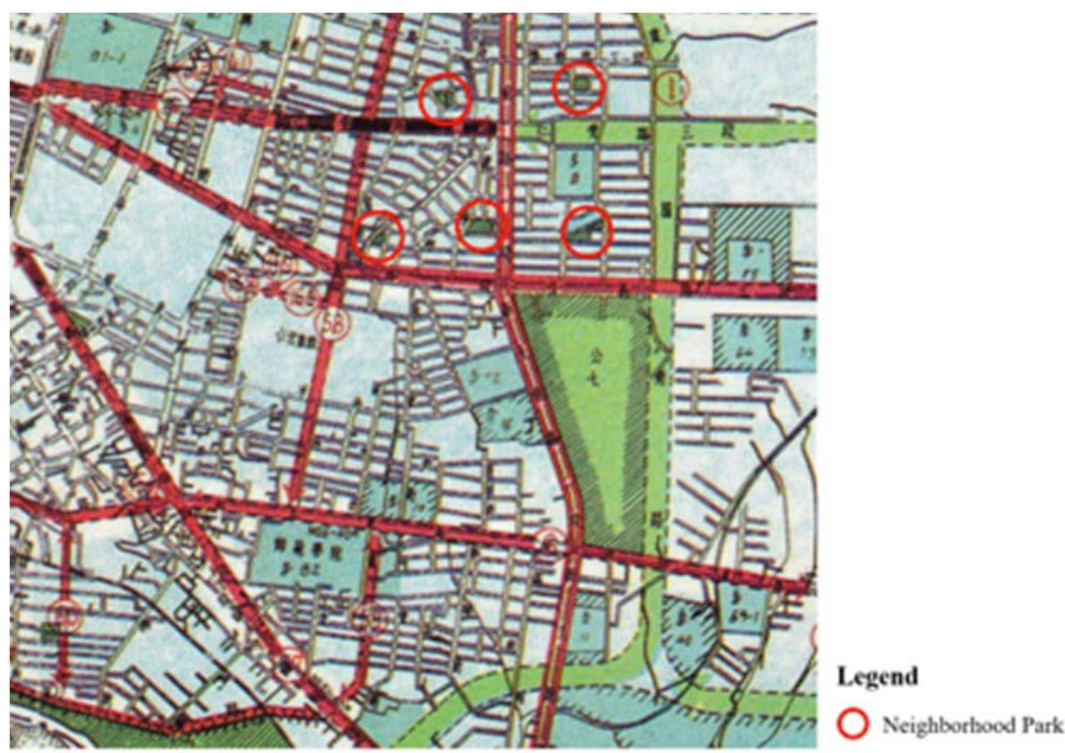

Fig. 2. The urban planning map of 195 I indicating neighbourhood parks north of the proposed Da-An Park (the slashed green area)

Min-Sheng Community marked the first master-planned neighbourhoods in Taipei following the US planning paradigm with local adjustment of intensifying the residential density to accommodate 45,000 people on I I0-hectare farmland. Through land consolidation and a well-constituted master plan, 25 medium- and small-size parks were organised around grid blocks of walk-up flats. Tree-lined streets amplified the green layout, and the $I^{\text {st }}$ floor setback for front-yard gardens, green sidewalks and firebreak alleys, green circle and refuge islands further spread the greenness to a district without large parks (Fig. 3). Similar to the neighbourhood unit proposal of Clarence Perry in 1910 that at least 10\% of the development should be zoned for open spaces and the schools be located adjacent to parks (Relph, 1987), Min-Sheng Community made the best use of the green open spaces to achieve an image of a sustainable neighbourhood. With the localised mixed-use zoning code, the major commercial activities were allocated around the collector street of Min-sheng East St. and the subdued retails and cafes around the minor street to keep the street life alive. At present day, Min-Sheng Community has evolved into a creative cluster and a hot spot for gentrification thanks to its perceived image of the most liveable urban village in Taipei. The extension of the MRT line into the south of the community's border exemplified the TOD and POD approaches of new urbanism and, unsurprisingly, further boosted up its property value (Kang and Yang, 20I3). In this regard, the real estate often flourishes around the coveted urban green, either through landscape urbanism or new urbanism, differing merely by a matter of degree. 


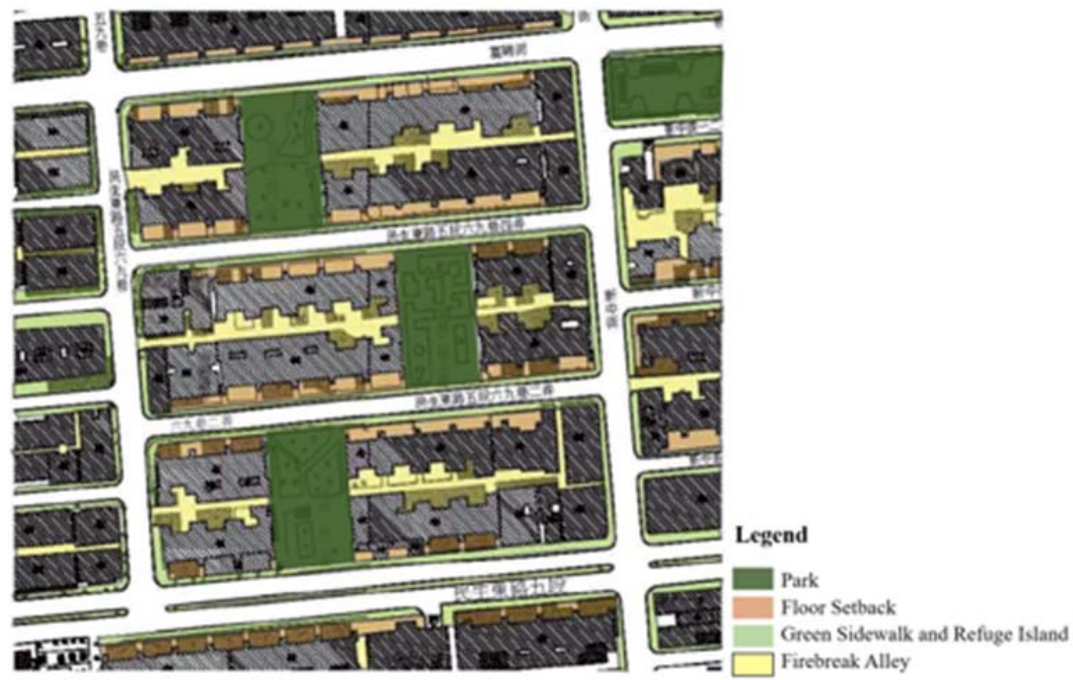

Fig. 3. A typical green layout of Min-Sheng Community

Other than the Min-Sheng Community model, many planned or designated urban parks and neighbourhood parks are not fully implemented due to the difficulty of land acquisition. The overall number of designated parks and green should be amounted to I,067 with total coverage of 2,000 hectares, yet so far only about 800 of the parkland have been developed, with total coverage of I,400 hectares, among which $40 \%$ are less than 2,000 square meters (Zhang and Wang, 2013). Prior to 1970s, the municipal fiscal budget was stringent to directly expropriate or purchase the land for neighbourhood parks, but with the introduced mechanisms of zone expropriation and land consolidation, the city of Taipei gradually procured the land to expand the park layout. Fig. 4 illustrates the general composition of the municipal Taipei today, the dotted greens embedded in the entire city precincts are the most accessible and frequently used green that speak less to the natural habitats than the daily environments of the urban communities. However, from the larger picture of urban ecology, they still provide nodal islands for the necessary niches and habitats of a variety of species. Taipei's neighbourhood parks are typically designed with similar features, including the most practical facilities of playground for children, exercise equipment, pavilion, plaza, and low-maintenance green elements. More interestingly, not until 2016 was the management of neighbourhood parks transferred from the Department of Civil Affairs to the professional Parks and Street Light Office of Public Works Department, implicating that the spatial role of neighbourhood parks were held more in line with the daily practices of civil life than a landscape resource. It is cherished as a shared inner court of the community, situated at accessible nodes along the everyday-life routines, and is particularly important for families with children and seniors. Before the emergence of larger urban parks, these inconspicuously designed neighbourhood parks were indispensable landscapes tightly meshed into the community life of Taipei, but rarely paid attention to by the tenet of landscape urbanism. 


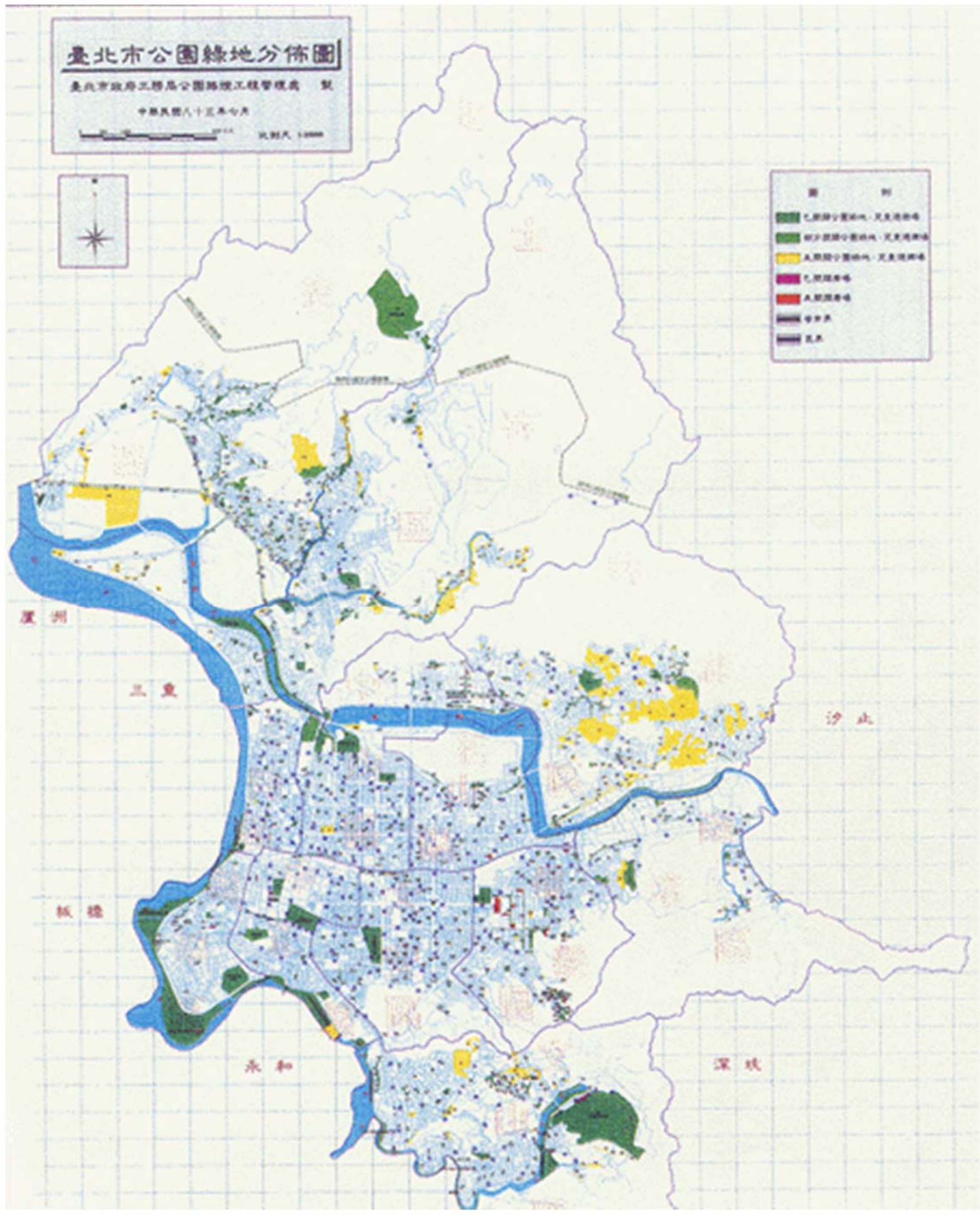

Fig. 4. The general layout of Taipei's green and blue system

In the compact city of Taipei, the green system of urban landscapes can also cover a range of open spaces not specifically zoned as parks, and school campuses are the most noteworthy among them. Fig. 5 indicates the school campuses of different levels around 
Da-An Park as possible green resources in a city of low park ratio, and the largest one being the NTU (National Taiwan University) campus south of Da-An. Since 1990, the open campus policy has opened up 153 elementary schools and 62 high schools for the community uses of exercises and recreation during the after-school hours (Zhang and Wang, 20I3), and along with the mostly open campuses of universities and colleges the availability of the green campuses has been understatedly catering to the need of neighbouring citizens. From the ecological perspective, the campus environment also serves the purposes of nurturing habitat islands and ecological 'sink' for the ecological 'source' of the surrounding mountains. The expansive ground of NTU campus sheltering diversified habitats of flora and fauna and sustaining the experimental farmland since the colonial period is in many ways a more mature and bio-friendly environment than DaAn Park. The connection between the two large green areas at the southern part of the city, where the river and mountains merge, with the proposed upgrading of Hsin-sheng South Road into an artery of blue and green is therefore a visionary project that also restores the collective memory of an irrigation channel which used to run through the middle of the street. The hint of landscape urbanism is almost patent.

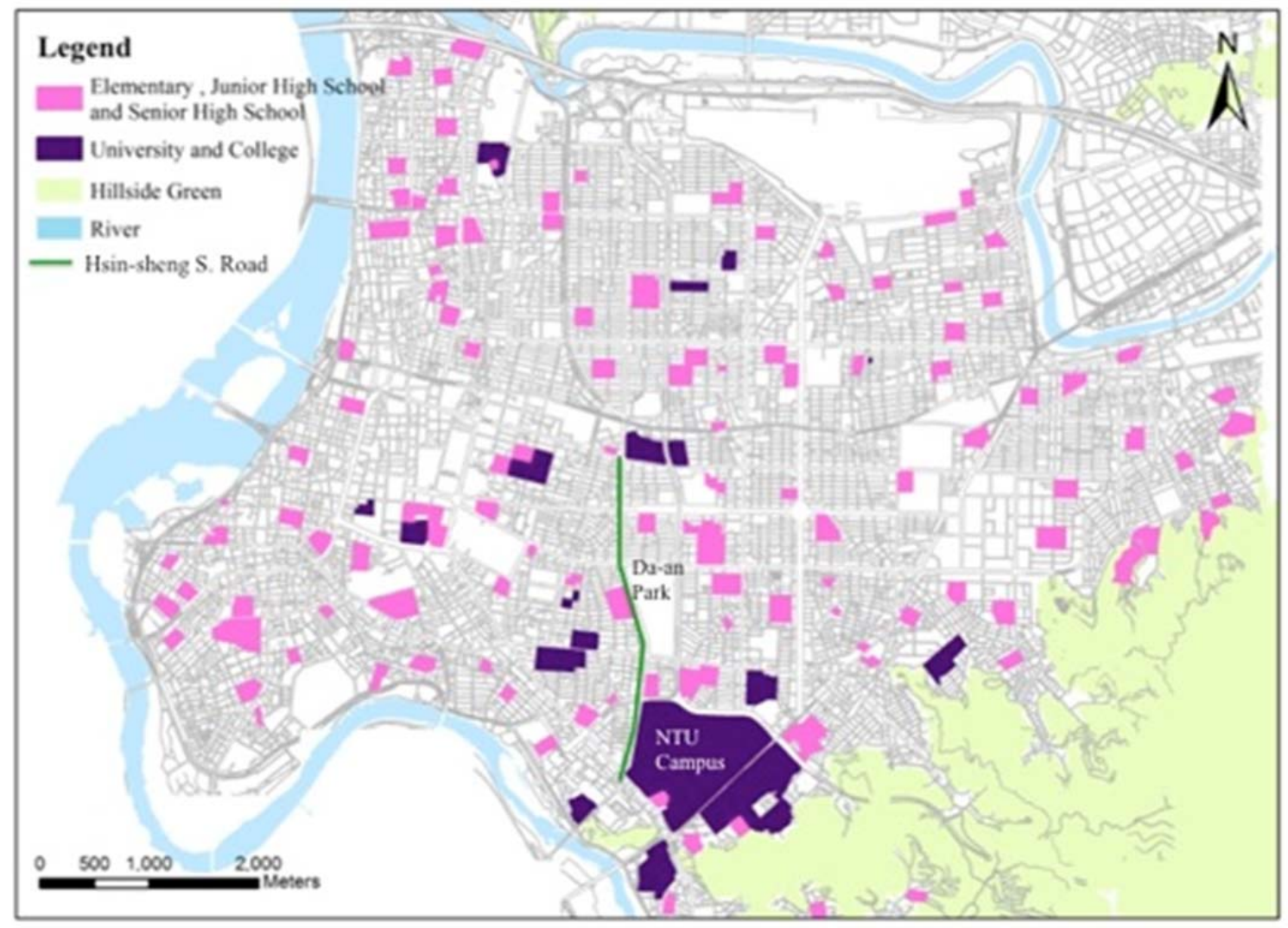

Fig. 5. The campus network of schools of different levels around Da-An Park

\subsection{The transitional-green, negotiated-green, and contended-green tactics of the counter- public non-parks}

The most deviant development of Taipei's green system occurred in 2009 when the city hosted the International Flora Expo and simultaneously cultivated 18 hectares of 
transitional green fields in the name of Taipei Beautiful. This controversial project encouraged both the public and private sectors to demolish the defunct buildings awaiting the upcoming urban renewal development then turned the vacant lots into open green experiments for 18 months in exchange for a bonus floor area ratio (FAR) up to maximum $10 \%$. It was criticised by activists against large-scale urban renewal for the cheap sale of the public interest of FAR to developers only with a short-term profit of 'fake parks' since, however the transitional green might be appreciated by the communities; the green would be eventually melted into solid gold of real estate. But due to the special designation of the transitional green, Taipei Parks and Street Lights Office did not administrate or manage them in their durations, which released certain degree of freedom normally forbidden or unforeseen in the uses of parks. Instead, many NGO adopted the transitional green to work on progressive experiments of urban green, ranging from community $\mathrm{P}$-patch, rain garden, reading garden, community oven, and even gay film festival, concert for the survival of urban minorities, bonfire for the sharing of indigenous hunter school, exchange bazaar of second-hand books, and many other events that challenged exclusions of counter-publics in public parks. These fragmented transitional green amounted to 72 in total and sporadically dispersed in 12 administrative districts of Taipei. Fig. 6 shows only a portion of these experimental green that redefined the urban public life indocile to the governance of institutionalised parks.

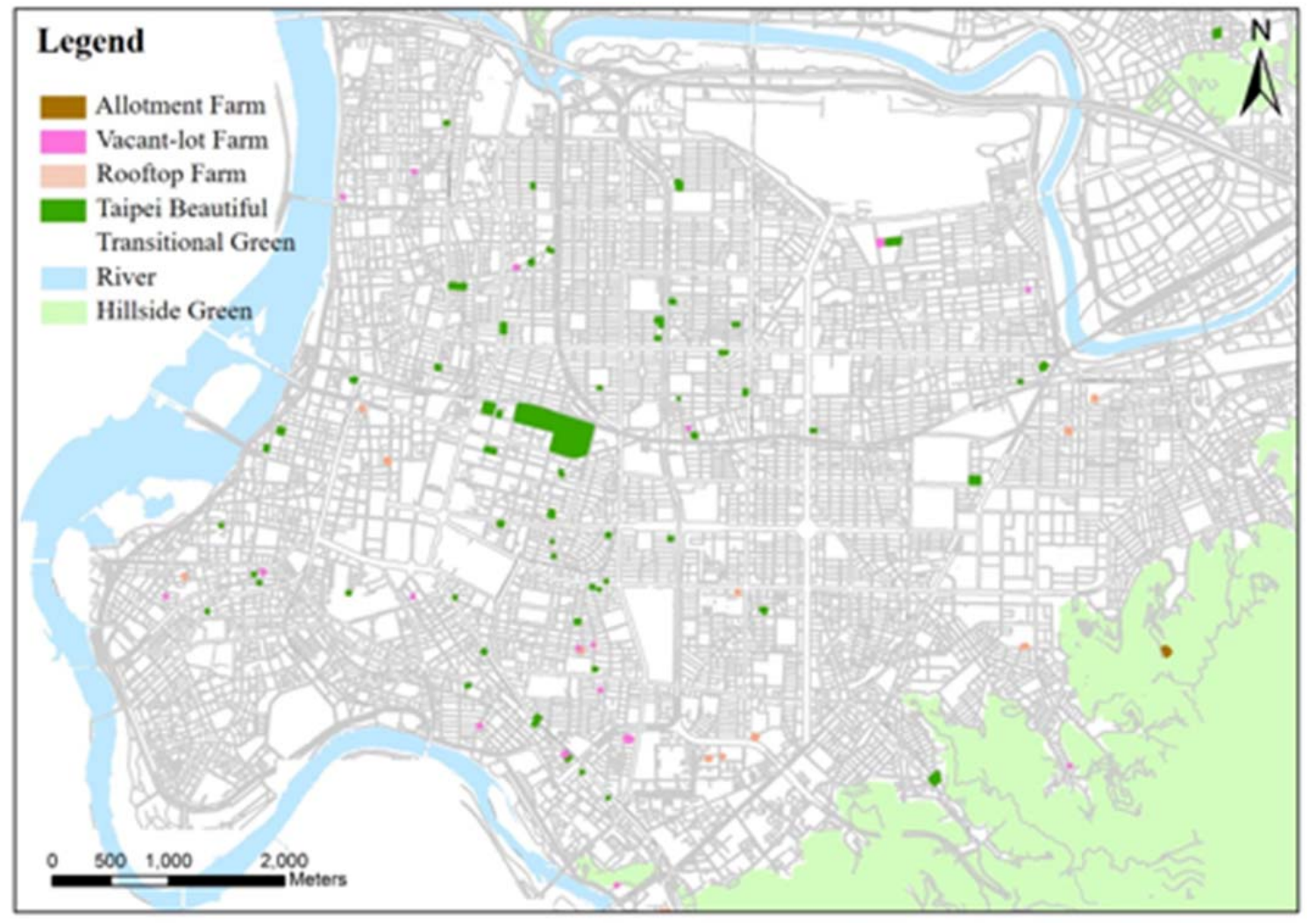

Fig. 6. The layout of the transitional green of Taipei Beautiful and the other temporary uses of urban farming 
Fig. 6 also displays urban farming in allotment, unused vacant lots, and rooftop, which are popular at grassroots level and now approved by the municipal government as legitimate green. Urban and weekend farmers establish their relationships with land through hands-on cultivation and periodic harvest and share of produces. While the districts of Guandu, Beito, and Shihlin retain large tracts of rice paddies, the relatively approachable dry farming of vegetables, herbs, and flowers is closer to the daily practices of urban farmers and deemed as a mode of leisure urbanism and a buffer between Taipei's agricultural past and the bustle and hustle of city life. Allotment farms appear on private as well as public land, and this localised interpretation of urban green through collective farming is closer to the spirit of urban commons rather than a public park. It raises the awareness of negotiated publicness amongst designated publicness and the participatory caretaking of urban land through do-it-yourself mechanism.

The statistics of 2013 estimated that the park and green area enjoyed by a citizen in Taipei is only $5.1 \mathrm{~m}^{2}$, much lower than that of $16 \mathrm{~m}^{2}$ per person in Seoul, $26.4 \mathrm{~m}^{2}$ in New York, $31.7 \mathrm{~m}^{2}$ in London, or even $8 \mathrm{~m}^{2}$ during the Japanese colonial time and the bottom limit of $9 \mathrm{~m}^{2}$ per person standardised by WHO. With such a predicament and existing constraints of urban governance, Taipei cannot depend on the methodology of landscape urbanism alone to explore the social imagination of the green. To combine the above-mentioned green resources around Da-An Park and NTU campus together, Fig. 7 may exemplify a composite effect of the dynamics between landscape urbanism and civic life in the Da-An district of Taipei. It is also a negotiation of boundary between landscape urbanism and new urbanism, adjusted to the context of an Asian compact city and mixed-use messy urbanism. The small neighbourhood parks and transitional green are implanted among the street blocks, which are sometimes cut or indented by intricate alleyways; while the larger urban parks and campuses anchor the intersections of a few tree-lined boulevards. If the general urban landscape lacks the grand scheme of large parks, vibrant street life, episodic yet accessible neighbourhood parks, and the sprawling green of the surrounding hills counterpoise such deficiency. And if a surveyor of urban green zooms in particular corners inside the street blocks, informal green and blue, such as overflowing green from apartment balconies or the front-yards of Japanese bungalows, salvaged trees from previous urban plans, autonomous arrangement of green in planters, a section of uncovered irrigation channel cherished by the community, or a singular landmark spider tree in seasonal bloom, may pop up to greet the onlooker or even signify the neighbourhood identity. Taipei is far from the ideal paradigm of Garden City, but from certain perspective, it self evolves into a more flexible and grassroots-induced 'planter city.'

The green patches and dots are discontinuous and the verticality of urban developments exacerbates the horizontal alignment of the green resources. Thanks to the rare opportunity of being crowned 2016 World Design Capital, the city government of Taipei overruled the priority of automobile transportation and widened the sidewalks for another line of tree and bike trail on Hsin-Sheng South Road. The downsize of car lanes decrease the flow and amount of automobiles to benefit both the pedestrians who enjoy street life and the bio-species that require the bridged green canopy between the larger habitats of Da-An Park and NTU campus. The accompanied sidewalk design 
intended to reflect the neighbouring community of Willow Den ${ }^{8}$ (Wen-Luo-Ting, 溫羅), particularly known for its diverse array of independent bookstores, live houses, cafes, and NGOs, and incorporated metal paving plates of quotes and poems collected from the contributions of different independent bookstores. But it immediately elicited another tension between publics and counter-publics, considering the exclusion of the selected words from a provocative gay bookstore.

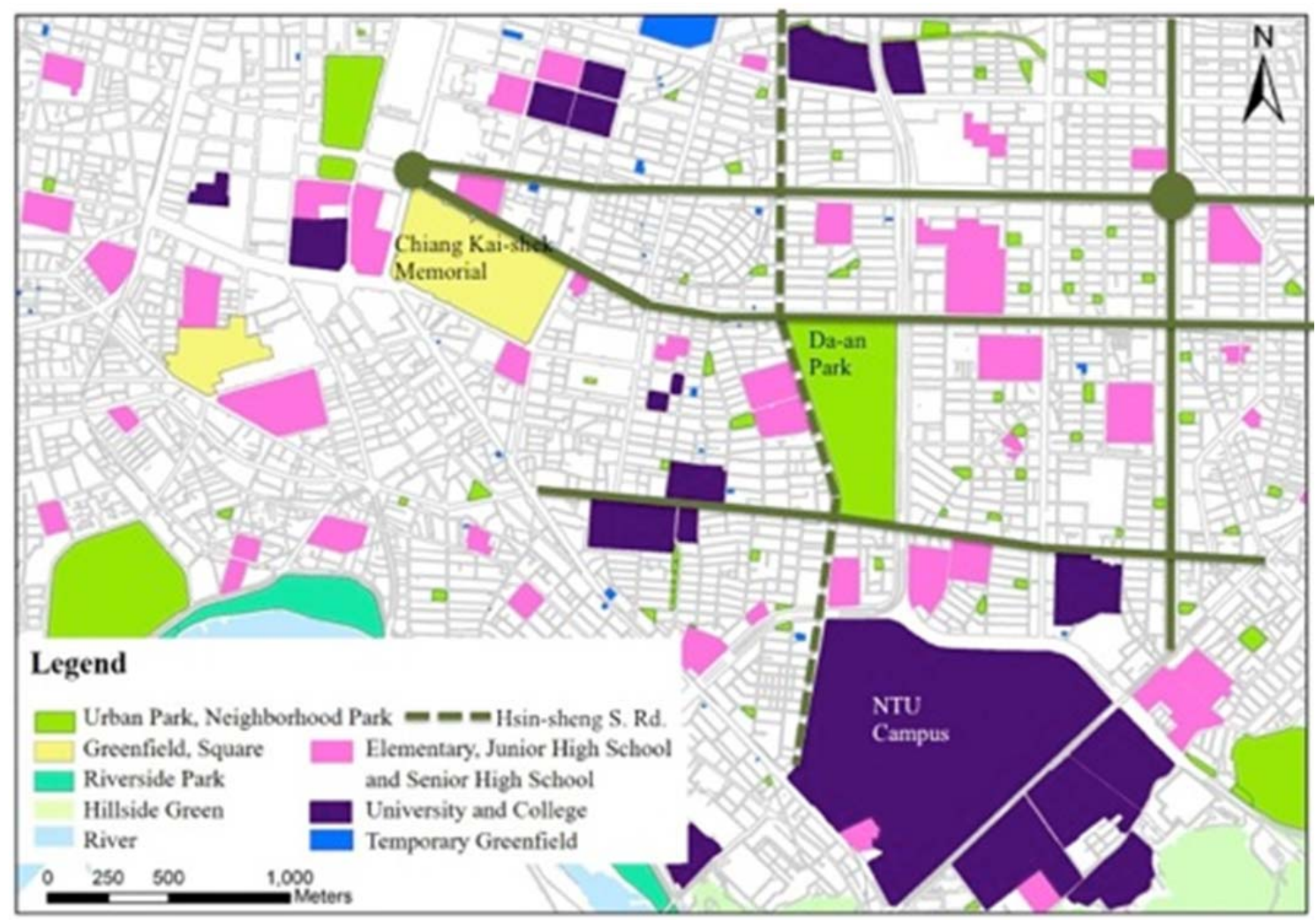

Fig. 7. The composite layout of green resources around Da-An Park and NTU campus

Hsin-Sheng South Road is a highly visible and 'public' boulevard adjacent to NTU campus, and as aforementioned, a Way to Heaven connecting many religious institutes. The invisibility of the gay bookstore plate can be read two-sided as a compromise to hide the representation of counter-publics in front of the general publics and/or as a strategic move to curtail direct confrontations and conflicts between the religious groups and the gay community so as to protect the tacit coexistence of both spheres. The decision was somewhat based on the controversies that already surfaced at two other sites of non-park in the same territory.

\footnotetext{
${ }^{8}$ Willow Den was intentionally named to project an alternative image of the Gong-Guan area near NTU campus. It's thus identified largely for its cultural foundation and milieu while Gong-Guan is easily associated with transportation hub, night market, and NTU. Willow Den community is a composition of residential neighbourhoods and many idiosyncratic and long-standing shops that have been renting spaces from landowners and subject to their lease terms and rent price setting.
} 
The first one happened in 2010 at a Taipei Beautiful temporary green where the landowner agreed to release the undeveloped private land for 18 months of 'public' use to acquire FAR bonus and invite the Willow Den Independent Consortium to manage the open lot. Though the members of the Consortium were fully aware of the fake-park criticism, they believed it was a rare platform for the counter-publics to voice up in a semi-public sphere and accepted the task of its collective management as a reading garden. In the following months, different independent bookstores took turns to arrange events according to their associated identities, including LGBTQ, feminism, leftism, Taiwanese indigenous tribes, religions, philosophical and sociological studies, and so on. They also contributed a symbolic text that represented each individual identity for a series of paving plates to exhibit a particular urban slice made of diverse social groups. When the landowner found out that the plate text of the gay bookstore quoted an extremely provocative poem by a famous poet, entitled The Subjectivity of My Anus, she called for an immediate removal of what seemed to be a blasphemy in language. The Consortium denied her request because she, compensated by extra floor areas, did not have any privilege on the land that had become 'public.' Guarded by the counter-publics' demand, the gay bookstore plate was firmly installed with other twelve bookstore texts on the garden ground; and due to the postponement of development, the garden still stands today, so do all the bookstore plates.

The second controversy continued the previous one when there was an opportunity for the public Taipower Company, located in the Willow Den neighbourhood, to install a public artwork in its territory, and the public art committee chose the site of a famous spider tree inside a fenced utility ground. The Taipower public art project demanded the artist group not only to remove the fence surrounding the spider tree for public appreciation, but also to collaborate with the Independence Consortium as a mode of participation. Knowing that the bookstore plates in the reading garden might be removed once the development matured into reality, the Consortium requested the artist group to make a vertical panel 'wall' to accommodate all the original texts next to the spider tree as a part of a permanent public art. The verticality of the art wall made the provocative poem too visible to be overlooked by the curious passers-by; and the nearby residential community, some of whose members were ardent and conservative Christians, soon reacted to the explicit text that confronted their moral value. The local Christians started to protest blatantly in front of the Taipower building and called for a direct dismantlement of the art panel. Different flyer and post-it messages appeared on or covered the gay poem, but counter messages from the gender-equality groups would quickly replace the hostile words of resentment. The daily battle of words turned into a tangible tension between the territorial community and the exogenous partisans of identity politics, but there wasn't much of a direct dialogue between two oppositional groups to sustain a public forum. The artist group eventually had to deal with the situation when publics and counter-publics couldn't meet each other halfway. The solution was to change the original single-surface panel that include words from 18 Willow Den independent bookstores into multi-surfaces which reflected the rentsidestepping reality of a few second-story or underground bookstores, and in the meanwhile hid the controversial quotes and the words from the closed-down bookstores inside 'pupil' holes that impeded direct viewing whereas seduced close-up gazing into (Fig. 8). The new tree-protecting art fence and the small opening under the 
spider tree became an alternative public space/counter-public non-park that invited sitting, reading, book exchanging, tree and blossom appreciation, and reflections on identity politics.

The largest area of counter-public non-park in the Willow Den vicinity used to be the most infamous neighbourhood condemned by the former mayor of Taipei Lee Teng-Hui as an urban tumour. Surrounded by the lush green of Guan-Yin Hill and fronting HsinDian River, the Treasure Hill ${ }^{9}$ settlement was a squatter village and a homeland for multiple layers of political immigrants and rural-urban immigrants. It was thereby zoned as an urban park according to Taipei's urban plan of 1990 to eradicate the illegal settlement and to respond to the demand of urban parks. The collective memories of the few were irrelevant to the modernizing and functional city, and not until the citizen uproar over the wholesale eviction of Park \#I4 and \#I5 and the critical voices from the Exposition of the Disempowered Communities did the city government begin to evaluate alternative measures.
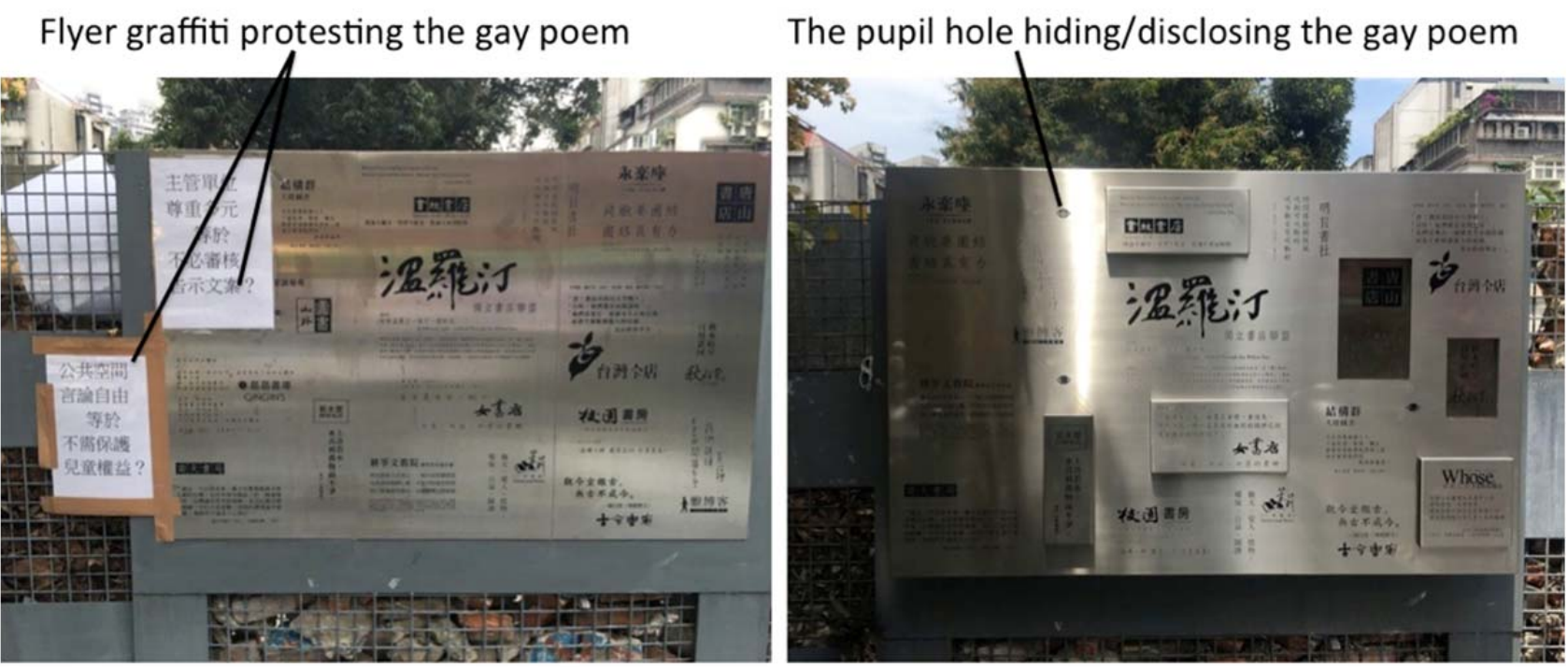

Fig. 8 The transformation of the Willow Den panel from single-surface into multi-layer

This informal congregation where squatters maintained their basic subsistence on piecemeal self-help mode was later preserved due to a sequence of local conservation actions $^{10}$ and lessons learned from the prior controversies of park implementation. Even more advanced than other static preservation cases of military-dependents' villages, the Treasure Hill settlement acquired the recognition of Taipei's cultural heritage committee to become the first settlement type of heritage in the city and an unprecedented dynamic conservation case that allowed the original squatters to sustain their in-situ living. By way of rather complicated processes of partial rezoning, spatial

\footnotetext{
${ }^{9}$ Originally the name of a historical shrine, later Treasure Hill also refers to the informal settlement flanking the shrine.

${ }^{10}$ A collaboration of Treasure Hill's underprivileged inhabitants and the third sector, particularly OURs (Organization of Urban Re-s) and NTU's Graduate Institute of Building and Planning.
} 
reprogramming and renovation, some of the settlement inhabitants opted to move back into their self-built units and pay under-market-value rent after legalised restoration by the government. It was at a crucial timing that the first Department of Cultural Affairs (DCA) was established within the administrative framework of Taipei, Treasure Hill was then re-envisioned as a co-living compound of artists, craftsmen, travellers, and original inhabitants, under the management of Taipei's International Artists Village and DCA. The creative cluster of arts and crafts is now an integral part of Treasure Hill and open to the public on daily basis, and such a program, though bringing in inevitable tourist gazes, offsets the criticism of the counter-publics' privatisation of public land.

The large tract of green landscape enveloping Treasure Hill remains its former zoning of a public park, altogether the settlement-park stimulates a special type of counter-public non-park that is unparalleled in Taiwanese planning and pubic history. The dynamic conservation blends the settlement daily life into the spatial fabric of a planned park and an organic settlement of gradual evolution, and it showcases how the settlement-into-park rationality may be counterbalanced by the alternative settlement-park in a more progressive mode of urban governance. The experiences of Treasure Hill cast an impact on the follow-up re-evaluation and reprogramming of informal settlement at the urban edge, such as the conservation case of the Toad Hill settlement. Registered as a cultural landscape heritage, Toad Hill is undertaking a rezoning process towards an ecovillage paradigm, an ongoing evolution beyond a settlement-park.

The coexistence of public parks and counter-public non-parks in the Da-an district blurs the boundaries between designated publicness and negotiated publicness, between zoning strategies and urban tactics, and between the social strata that separate publics and counter-publics. The political struggles behind the production of regulated urban parks and informal public greens in Taipei unexpectedly facilitate the development of a more democratic and inclusive city that upholds variegated green infrastructures and a broader comprehension of public history.

\section{Conclusion}

Urban parks are not neutral green spaces under the rules of zoning or the theory of landscape urbanism, and their productions are the consequences of land politics and eminent domain that accentuate the prominence of nature, leisure, and publicness. This research looks into the landscape dialectics between public parks and counter-public nonparks and the spatial politics regarding their implementations in the city of Taipei. The counter-publics' claim for their rights to the city and the movement of urban conservation, following the democratising process, challenged the modernist zoning rationales of transforming settlement-into-park in the name of publicness, and fostered a more inclusive and dynamic paradigm of settlement-park that integrate the socio-spatial fabrics of the settlement with its environing nature. The true publicness may not only lie in the public sphere that is achieved by pre-empting the extant cultural landscapes and excluding the subaltern counter-publics, but also acknowledge the collective voices and experiences of the underprivileged to approximate a holistic public. 


\section{References}

Barlow, T. (1997). Introduction: on "colonial modernity”, in T. Barlow (ed.), Formations of Colonial Modernityin East Asia, Durham, NC: Duke University Press: I-20.

Connolly, P. (1995). Kerb: Journal of Landscape Architecture, no I, Melbourne: RMIT University Press.

Corner, J. (2006). Terra Fluxus, in C. Waldheim ed. The Landscape Urbanism Reader, N.Y.: Princeton Architectural Press, 2 I-34.

Cranz G. (1982). The Politics of Park Design: A History of Urban Parks in America. Cambridge, MA: MIT Press.

Czerniak, J. (2007). Introduction: Speculating on Size, in J. Czerniak and G. Hargreaves. eds. Large Parks. N. Y.: Princeton Architectural Press, 19-34.

Fraser, N. (1990). Rethinking the Public Sphere: A Contribution to the Critique of Actually Existing Democracy, Social Text (Duke University Press), 25/26: 56-80.

Gould K.A. and Lewis T.L. (2016). Green Gentrification: Urban Sustainability and the Struggle for Environmental Justice. New York: Routledge.

Harvey, D. (1997). The New Urbanism and the Communitarian Trap, Harvard Design Magazine, Winter/Spring, Number I.

Harvey, D. (200I). Globalization and the "Spatial Fix", Geographische Revue, 2, 23-30.

Hayden, D. (1996). Urban Landscapes as Public History, in The Power of Place: Urban Landscapes as Public History, Cambridge, MA: MIT Press.

Higgins M. (1995). Commons Levy Defeated, Seattle Post-Intelligencer, 20 September, p. I.

Huang, S.C. (20I2). Green Bulldozer: The Squatters, Parks, Nature estate, and institutionalized landscape of 90's Taipei. Taipei: Pots Publication.

Kang, M.J. (2015). The Unfinished Business of Taipei's Post-World War II Urban and Housing Development, in H.F. Lin and M.H. Gao ed., The planned city affairs - The urban development history of post World War II Taipei, Taipei: Garden City Publisher, 26-33.

Kang, M.J. and Yang S.S. (2013). Creative Cluster or Community Economy? The Transformation and Restructuring of Min-Sheng Community, in Proceedings of the 7th Conference of IFoU (International Forum on Urbanism): Creativity and Urban Evolution, 162-175. 
The Spatial Production of Public Parks and Counter-public Non-parks in Taipei

Kampourakis, I. (20I6). Nancy Fraser: Subaltern Counterpublics. Critical Legal Thinking (blog), November 6, retrieved 2019/5/2I, http://criticallegalthinking.com/2016/I I/06/nancy-frasersubaltern-counterpublics/.

Kelbaugh, D. (2002). Repairing the American Metropolis: Common Place Revisited, Seattle: University of Washington Press.

Liu, D.Q. (2005). The Study of the Formation and Development of Taiwan's Parks and Green Fields - the Case of Taipei, in Urban Governance Forum of Hualien County and Hawaii County, Hualien.

McCann, E., and Ward, K. (20I5). Thinking through Dualism in Urban Policy Mobilities, International Journal of Urban and Regional Research, 39(4), 828-830.

McHarg, I.L. (1969). Design with Nature, Garden City, NY: Natural History Press.

Mostafavi, M., C. Najle, and Architectural Association (2003). Landscape Urbanism: A Manual for the Machinic Landscape. London: Architectural Association.

Relph, E. (1987). The Modern Urban Landscape, Baltimore: The Johns Hopkins University Press.

Speckhardt, L. (20I3). High Times, Landscape Architecture Magazine, retrieved 2019/5/2I, https://landscapearchitecturemagazine.org/2013/01/25/high-times/

Steuteville, R. (20II). Street Fight: Landscape Urbanism versus New Urbanism, retrieved 2019/5/2I, https://www.cnu.org/publicsquare/201 l/06/09/street-fight-landscape-urbanismversus-new-urbanism

Tsai H.N. (199I). The Establishment Processes of Taiwan's Urban Parks, 1895-1987, Dissertation, Graduate Institute of Building and Planning, National Taiwan University.

Turner, T. (1996). City as Landscape, London: E\&FN Spon.

Waldheim, C. (2002). Landscape Urbanism: A Genealogy, in Praxis 4: Landscapes, I0-17.

Warner, M. (2002). Publics and Counterpublics. New York: Zone Books.

Wu, P.S. (2010). Walking in Colonial Taiwan: A Study on Urban Modernization of Taipei, I8951945, Journal of Asian Architecture and Building Engineering, 9:2, 307-3I4.

Zhang, S. and Wang J.H. (20I3). Taipei Unveiled, Taipei: Garden City. 